\title{
TRANSPARANSI PENGELOLAAN DANA DESA DI DESA MELILIAN KECAMATAN GELUMBANG KABUPATEN MUARA ENIM
}

\author{
Umi Purwanti \\ Staf Dosen Fakultas Ilmu Administrasi Universitas Sjakhyakirti \\ Email: umi_purwanti@unisti.ac.id
}

\begin{abstract}
Transparency is one of the principles that can guarantee access or freedom for all people to obtain information about the administration and management carried out by the government. With the principle of transparency, it is hoped that the Melilian Village government, Gelumbang District, will manage the Village Fund transparently and involve the Village community. This study aims to describe the management of Village Funds and the mechanisms for managing Village Funds carried out by the Melilian Village Government, Gelumbang District, Muara Enim Regency. The method used in this research is descriptive qualitative method. Data collection techniques in this study include, observation, interviews and documentation. The results showed that the management of the Village Fund carried out by the Melilian Village government, Gelumbang District, was in accordance with the applicable laws and regulations and involved the community from the planning, implementation, administration, reporting and accountability stages to the delivery of development results. Based on the transparency indicator, it shows that there is availability of document accessibility as well as completeness, clarity and convenience for the public to access information as a whole with the installation of billboards and information boards at several points. This study concludes that Melilian Village, Gelumbang Subdistrict, has carried out the process of the Village Fund management mechanism in stages by involving several related elements including the people of Melilian Village, Gelumbang District.
\end{abstract}

Keywords: Transparency, Village Fund, Village Government

\begin{abstract}
ABSTRAK
Transparansi merupakan salah satu prinsip yang dapat menjamin akses atau kebebasan bagi seluruh masyarakat untuk memperoleh informasi tentang penyelenggaraan dan pengelolaan yang dilakukan oleh pemerintah. Dengan adanya prinsip transparansi diharapkan pemerintah Desa Melilian Kecamatan Gelumbang melakukan pengelolaan Dana Desa dengan transparan serta melibatkan masyarakat Desa. Penelitian ini bertujuan untuk mendeskripsikan pengelolaan Dana Desa dan mekanisme pengelolaan Dana Desa yang dilakukan oleh pemerintah Desa Melilian Kecamatan Gelumbang Kabupaten Muara Enim. Metode yang digunakan dalam penelitian ini adalah metode kualitatif deskriptif. Teknik pengumpulan data dalam penelitian ini meliputi, observasi, wawancara dan dokumentasi. Hasil penelitian menunjukan bahwa pengelolaaan Dana Desa yang dilakukan oleh pemerintah Desa Melilian Kecamatan Gelumbang sudah sesuai dengan peraturan Perundang-undangan yang berlaku serta melibatkan masyarakat mulai dari tahapan perencanaan, pelaksanaan, penatausahaan, pelaporan dan pertanggungjawaban sampai dengan penyerahan hasil pembangunan. Berdasarkan indikator transparansi menunjukan bahwa adanya ketersediaan aksesibilitas dokumen serta adanya kelengkapan, kejelasan dan kemudahan bagi masyarakat untuk mengakses informasi secara menyeluruh dengan adanya pemasangan baliho dan papan informasi di beberapa titik. Penelitian ini menyimpulkan bahwa Desa Melilian Kecamatan Gelumbang sudah menjalankan proses mekanisme pengelolaan Dana Desa secara bertahap dengan melibatkan beberapa unsur terkait termasuk masyarakat Desa Melilian Kecamatan Gelumbang.
\end{abstract}

Kata Kunci: Transparansi, Dana Desa, Pemerintah Desa

\section{A. PENDAHULUAN}

Pelaksanaan pemerintahan yang baik (good governance) merupakan salah satu proses yang diterapkan dalam sebuah organisasi, baik organisasi swasta maupun pemerintahan untuk menentukan keputusan dan kebijakan dalam sebuah lingkup organisasi. Tatalaksana pemerintahan yang baik, walaupun tidak dapat menjamin sepenuhnya segala sesuatu akan menjadi sempurna namun, apabila dipatuhi 
jelas dapat mengurangi penyalahgunaan kekuasaan dan korupsi. Untuk mewujudkan tata kelola pemerintahan yang baik, tentunya diperlukan sepuluh prinsip-prinsip good governance. Salah satunya adalah prinsip transparansi.

Transparansi merupakan salah satu prinsip yang dapat menjamin akses atau kebebasan bagi seluruh masyarakat untuk memperoleh informasi tentang penyelenggaraan dan pengelolaan yang dilakukan oleh pemerintah, seperti informasi tentang kebijakan, proses pembuatan dan pelaksanaannya, serta hasilhasil yang akan dicapai. Transparansi adalah adanya kebijakan terbuka bagi seluruh pengawasan. Sedangkan yang dimaksud dengan informasi adalah adanya informasi mengenai setiap aspek kebijakan pemerintah yang dapat dijangkau oleh seluruh masyarakat (Krina, 2003).

Transparansi dapat mengatasi munculnya monopoli kekuasaan pembuat kebijakan. Dengan adanya transparansi, cheks and balance akan dapat difungsikan dengan baik. Menurut Moore (2008) transparansi juga dapat mengurangi tingkat penyimpangan anggaran, seperti korupsi. Sehingga upaya untuk meningkatkan penyelenggaraan pemerintah mudah diwujudkan.

Transparansi keuangan dalam pemerintahan desa menjadi aspek utama penentu keberhasilan dalam pembangunan desa. Hal ini sesuai dengan Peraturan Pemerintah Republik Indonesia No 60 Tahun 2014 Pasal 2 Tentang Dana Desa dikelola secara tertib, taat pada ketentuan peraturan perundang-undangan, efisiensi, ekonomis, efektif, transparan, dan bertanggung jawab dengan memperhatikan rasa keadilan dan kepatutan serta mengutamakan kepentingan masyarakat setempat.

Pemerintah desa merupakan lingkup yang terkecil dalam sebuah pemerintahan Republik Indonesia, oleh karena itu kepala desa maupun perangkat desa harus dapat memahami tugas pokok dan fungsi (tupoksi) dalam upaya meningkatkan kinerja pemerintah desa. Dengan adanya kinerja yang baik dalam pemerintah desa program-program yang direncanakan oleh pemerintah desa dapat dijalankan secara efektif dan efisien. Pemerintah desa juga memiliki peran penting dalam pembagunan desa. Oleh karena itu transparansi dalam pengelolaan dana desa harus dijalankan secara maksimal, sehingga tujuan untuk pemerataan kesejahteraan masyarakat dapat terwujud (Miftahuddin, 2018:2).

Berdasarkan penjelasan Undang-Undang No. 6 Tahun 2014, Dana Desa merupakan dana yang bersumber dari Anggaran Pendapatan dan Belanja Negara (APBN). Setiap desa akan mengelola tambahan anggaran berupa Dana Desa yang akan diterima secara bertahap. Dengan adanya Dana Desa dapat menjadikan sumber pemasukan di setiap desa akan semakin bertambah. Dengan bertambahnya pendapatan desa yang diberikan oleh pemerintah dapat meningkatkan taraf hidup masyarakat desa.

Namun dengan adanya Dana Desa juga dapat memunculkan permasalahan yang baru dalam pengelolaan dana desa, pemerintah desa diharapakan dapat mengelola dana desa dengan baik sebagaimana yang telah di jelaskan dalam peraturan perundang-undangan bahwasanya dana desa dikelola secara efisien, ekonomis, efektif, transparan dan bertanggung jawab dengan memperhatikan rasa keadilan dan kepatuhan serta mengutamakan kepentingan masyarakat (Miftahuddin, 2018:2).

Berdasarkan hasil observasi awal yang dilakukan di Desa Melilian Kecamatan Gelumbang merupakan sebuah desa yang cukup jauh dari pusat kota, oleh karena itu tidak semua masyarakat Desa Melilian Kecamatan Gelumbang memahami apa itu transparansi, walaupun pemerintah Desa Melilian Kecamatan Gelumbang sudah memahami apa itu transparansi, akan tetapi, masyarakat sendiri masih memahami transparansi itu dengan pemahaman mereka sendiri bahwa Dana Desa di desa tersebut sudah transparansi dalam pengelolaannya. Adapun karakteristik dan kondisi sosial masyarakat Desa Melilian Kecamatan Gelumbang jika melihat dari segi persatuan masyarakat masih terbilang tinggi dalam partisipasi melakukan musyawarah untuk pembangunan desa dan juga sikap gotongroyong yang masih kuat. 
Berdasarkan pengamatan yang saya lakukan dengan menggunakan indikator transparansi bahwa adanya ketersediaan aksesibilitas dokumen seperti dokumen buku APBK dan buku realisasi anggaran Dana Desa yang bisa didapatkan di Kantor Pemerintah Desa dan juga dirumah Kepala Desa yang telah tersusun rapi agar mudah untuk diakses oleh masyarakat. Kemudian adanya kejelasan, keterbukaan serta kemudahan bagi masyarakat untuk dapat mengakses informasi tentang rincian anggaran Dana Desa dan juga hasil dari pembangunan dengan adanya pemasangan baliho di beberapa titik yang dilakukan oleh pemerintah Desa Melilian Kecamatan Gelumbang.

Desa Melilian Kecamatan Gelumbang menerima Dana Desa sejak tahun 2015. Dana Desa yang telah diterima sejak Tahun 2015 tersebut digunakan untuk empat (4) bidang yaitu meliputi, pemberdayaan masyarakat, pembinaan masyarakat, pembinaan sarana sosial dan prasarana (pembangunan).

Oleh karena itu perlu kiranya untuk melakukan penelitian di Desa Melilian Kecamatan Gelumbang untuk melihat proses mekanisme dan transparansi pengelolaan Dana Desa. Transparansi dalam pengelolaan Dana Desa sangat dibutuhkan untuk mendukung pembangunan dan perkembangan desa menjadi lebih baik, Berdasarkan uraian diatas, maka penulis tertarik untuk melakukan penelitian yang berjudul "Transparansi Pengelolaan Dana Desa di Desa Melilian Kecamatan Gelumbang Kabupaten Muara Enim.

\section{Rumusan Masalah}

Berdasarkan latar belakang diatas, maka dapat dirumuskan fokus dalam penelitian ini yaitu sebagai berikut :

1. Bagaimana Mekanisme pengelolaan Dana Desa di Desa Melilian Kecamatan Gelumbang Kabupaten Muara Enim?

2. Bagaimana transparansi pengelolaan Dana Desa di Desa Melilian Kecamatan Gelumbang Kabupaten Muara Enim?

\section{B. KAJIAN PUSTAKA \\ Teori Transparansi}

Menurut Ratminto (Anggraini, 2013:4) menyatakan, bahwa transparansi dalam penyelenggaraan pelayanan publik adalah terbuka, mudah dan dapat diakses oleh semua pihak yang membutuhkan secara memadai dan mudah dimengerti oleh seluruh masyarakat. Transparansi dapat menjamin akses atau kebebasan bagi setiap orang untuk memperoleh informasi tentang penyelenggaraan pemerintahan, yaitu informasi tentang kebijakan, proses pembuatan dan pelaksanaannya serta hasil yang dicapai dari kebijakan tersebut (Rahmanurrasjid, 2008:85). Transparansi dibangun berdasarkan kebebasan arus informasi. Proses dan informasi, secara langsung dapat diterima oleh mereka yang membutuhkan informasi.

Transparansi merupakan suatu tindakan yang dilakukan oleh pemerintah untuk memberikan kemudahan kepada masyarakat dalam mengakses informasi. Sehingga dengan adanya transparansi dapat membangun kepercayaan masyarakat melalui adanya akses yang memadai untuk mendapatkan informasi yang fakta dan akurat. Keterbukaan atau transparansi dapat di artikan sebagai tindakan yang memungkinkan suatu persoalan dapat menjadi jelas, serta mudah untuk difahami oleh kalangan masyarakat dan dapat dibuktikan kebenarannya sehingga tidak ada lagi permasalahan (Mulyaningsih: 2019: 6).

\section{Indikator Transparansi}

Adapun indikator transparansi dalam model pengukuran pelaksanaan Good Governance menurut Kristianten (Mulyaningsih: 2019: 7) transparansi dapat diukur melalui beberapa indikator yaitu :

1. Adanya ketersediaan aksesibilitas dokumen

2. Adanya kejelasan dan kelengkapan informasi

3. Adanya keterbukaan proses

4. Kerangka regulasi yang menjamin transparansi 
E. ISSN : 2746-1629

\section{Prinsip-Prinsip Transparansi}

Humanitarian Forum Indonesia (Irfan, 2017:18) mengemukakan ada enam (6) prinsip dalam transparansi yaitu sebagai berikut :

1. Adanya informasi yang mudah dipahami serta dapat diakses mengenai informasi dana, cara pelaksanaan, proses pelaksanaan, serta bentuk bantuan atau program.

2. Adanya informasi yang dipublikasikan serta adanya media yang mengakses informasi mengenai proses kegiatan dan detail keuangan

3. Adanya laporan berkala yang disertai dokumen atau bukti mengenai pendayagunaan sumberdaya alam dalam perkembangan proyek yang dapat diakses oleh umum/publik.

4. Adanya laporan tahunan mengenai keuangan serta pelaksanaan kegiatan yang dilakukan oleh desa dan disertai dengan dokumen atau bukti.

5. Adanya Website atau media yang digunakan dalam mempublikasikan kegiatan yang dilakukan dalam organisasi desa

6. Adanya Pedoman dalam melakukan penyebaran informasi.

\section{Pemerintahan Desa}

Desa merupakan organisasi pemerintahan terendah dan merupakan suatu organisasi pemerintahan yang secara langsung brhubungan dengan masyarakat. Pemerintah Desa adalah unsur penyelenggaraan pemerintahan desa. Pemerintah Desa merujuk pada perangkat desa yang terdiri dari Kepala Desa dan perangkat desa lainnya, yang merupakan bagian integral dari aparatur Pemerintahan Indonesia (Taliziduhu,1983:50).

\section{Peran Pemerintah Desa Dalam Pembangunan}

Dalam pembangunan desa peran pemerintah desa sangat penting baik dalam pembangunan desa maupun pemberdayaan masyarakat, sebagaimana kita ketahui bahwa masyarakat yang lebih mengetahui apa yang mereka butuhkan sampai masyarakat tersebut merasa bahwa hidupnya sudah terjamin, adil, aman, dan sejahtera baik dari segi perekonomian maupun pambangunan. Ada beberapa peran pemerintah desa sebagai pelaksana pemerintah yaitu sebagai berikut :

1. Pengelolaan keuangan desa

2. Menggerakkan partisipasi masyarakat dalam pelaksanaan pembangunan

3. Menggerakkan pasrtisipasi masyarakat dalam menciptakan ketertiban dan keamanan masyarakat.

4. Pemberdayaan masyarakat desa

\section{Pengelolaan Keuangan Desa}

Keuangan desa dapat didefinisikan sebagai semua hak dan kewajiban desa yang dapat dinilai dengan uang, serta segala sesuatu baik berupa uang maupun berupa barang yang dapat dijadikan milik desa berhubung dengan pelaksanaan hak dan kewajiban tesebut (Soleh, 2015:3). Berdasarkan Permendagri Nomor 113 Tahun 2014 tentang pengelolaan keuangan desa merupakan keseluruhan kegiatan yang meliputi perencanaan, pelaksanaan, penatausahaan, pelaporan serta pertanggungjawaban keuangan desa.

1. Dalam perencanaan pembangunan desa harus diselenggarakan dengan melibatkan masyarakat desa dalam musyawarah perencanaan pembangunan desa. Jika melihat dari segi dokumentatif perencanaan dan pembangunan desa tertuang dalam Rencana Pembangunan Jangka Menengah Desa (RPJMDes) yang hanya berlaku selama enam tahun dan Rencana Pembangunan Tahunan Desa atau disebut dengan Rencana Kerja Pemerintah Desa (RKPDes) dan Anggaran Pendapatan Dan Belanja Desa (APBDes) yang berlaku satu tahun. Rencana Kerja Pemerintah Desa merupakan rencana program kegiatan desa yang dijadikan sebagai acuan dalam menyusun anggaran pendapatan dan belanja desa.

2. Pelaksanaan pengelolaan keuangan desa meliputi beberapa prinsip yang harus dipenuhi yaitu seluruh penerimaan dan pengeluaran desa harus dilaksanakan melaui Rekening Kas Desa, untuk mencegah terjadinya penyelewengan keuangan desa pelaksanaan kegiatan desa harus disertai dengan dokumen sebagai bukti. 
3. Penatausahaan keuagan desa merupakan kegiatan pencatatan yang dilakukan oleh Bendahara desa. Kemudian Bendahara diwajibkan untuk melakukan pencatatan terhadap seluruh transaksi baik pengeluaran maupun penerimaan.

4. Pelaporan memiliki beberapa Indikator yaitu: kepala desa menyampaikan laporan realisasi pelaksanaan APBDes kepada Bupati/walikota, Laporan semester pertama dilaporkan paling lambat akhir bulan Juli tahun berjalan, Laporan akhir tahun dilaporkan paling lambat bulan Januari tahun berikutnya.

5. Pertanggungjawaban, Indikator pertanggungjawaban meliputi, kepala desa menyampaikan laporan realisasi pelaksanaan Anggaran Pendapatan Belanja Desa kepada bupati/walikota sebagai pertanggungjawaban, laporan pertanggungjawaban realisasi pelaksanaan APBDes terdiri dari pendapatan, belanja serta pembiayaan, kemudian laporan pertanggungjawaban disampaikan kepada masyarakat secara tertulis maupun melalui media yang dapat diakses dan mudah dijangkau.

\section{Dana Desa}

Dalam Undang-Undang Nomor 6 Tahun 2014 Pasal 1 Tentang Desa. Dana Desa "merupakan dana yang bersumber dari Anggaran Pendapatan dan Belanja Negara (APBN) yang diperuntuhkan bagi Desa yang ditransfer melalui Anggran Pendapatan dan Belanja Daerah (APBD) Kabupaten/Kota dan digunakan untuk membiayai seluruh penyelenggaraan pemerintahan, pelaksanaan pembangunan, pembinaan kemasyarakatan serta pemberdayaan masyarakat dapat berjalan dengan baik". Berdasarkan Undang-Undang Nomor 6 Tahun 2014 Pasal 2 Tentang Desa. Dana Desa harus dikelola secara tertib, taat pada ketentuan peraturan perundangundangan, efisien, ekonomis, efektif, transparan dan bertanggungjawab dengan memperhatikan rasa keadilan dan kepatuhan serta mengutamakan kepentingan masyarakat.

\section{METODE PENELITIAN}

Penelitian ini menggunakan pendekatan kualitatif dengan jenis penelitian deskriptif, penelitian ini bertujuan dapat memberikan gambaran secara terarah dan jelas baik secara lisan maupun tulisan yang didapatkan dari hasil pengamatan perilaku yang diamati secara sistematis yang berkaitan dengan objek penelitian dengan memberikan data dan informasi yang akurat. Informan dalam penelitian ini adalah sebagai berikut:

1. Kepala Desa

2. Sekretaris Desa

3. Bendahara Desa

4. Tokoh Masyarakat

5. Masyarakat

\section{Teknik Pengumpulan Data}

1. Observasi, dalam penelitian ini peneliti langsung terjun ke lapangan untuk melihat kegiatan yang dilakukan oleh pemerintah desa dalam melakukan pengelolaan dana desa.

2. Wawancara

3. Dokumentasi, dengan cara mengumpulkan berbagai pengetahuan baik itu dari buku yang tersedia di desa Melilian Kecamatan Gelumbang maupun jurnal penelitian yang dilakukan sebelumnya yang berkaitan dengan permasalahan dalam penelitian ini. Kemudian data yang dapat dikumpulkan dari buku laporan tahunan, browsur informasi, papan informasi, baliho, RPJMK, APBDes, maupun RKPDes terkait dengan transparansi pengelolaan dana desa di desa Melilian Kecamatan Gelumbang Kabupaten Muara Enim.

\section{Teknik Analisis Data}

Menurut Miles dan Huberman kegiatan analisis terdiri dari tiga alur kegiatan yang terdiri secara bersamaan yaitu reduksi data, penyajian data, penarikan kesimpulan/verifikasi (Silalahi,2000:339). 
E. ISSN : 2746-1629

D. DATA DAN HASIL PENELITIAN Mekanisme Pengelolaan Dana Desa di Desa Melilian Kecamatan Gelumbang Kabupaten Muara Enim

Mekanisme pengelolaan dana desa di Desa Melilian Kecamatan Gelumbang pada tahun 2019 diawali dengan melakukan perencanaan APBK desa yang diajukan kepada pihak kecamatan dan di sampaikan kepada pihak DPM atau keuangan daearah, kemudian setelah di cek kebenaran dokumen APBK maka dana itu dikeluarkan melalui rekomendasi DPM kepada dinas keuangan maka dinas keuangan akan melimpahkan dana tersebut kepada Bank BPD yang terletak di Desa Lembak.

Mekanisme yang dilakukan oleh pemerintah Desa Melilian Kecamatan Gelumbang pada tahun anggaran 2019 yaitu setelah dana tersebut dikeluarkan oleh pihak Bank maka Desa Melilian Kecamatan Gelumbang Melakukan pra musyawarah untuk membahas perencanaan dan proses pelaksanaan pembangunan desa pada tahun 2019 yang akan dilakukan di Desa Melilian Kecamatan Gelumbang. Pencairan anggaran Dana Desa pada tahun 2019 dilakukan secara bertahap adapun tahapan yang pertama yaitu berjumlah $40 \%$, tahapan kedua berjumlah $40 \%$, kemudian tahapan ketiga berjumlah $20 \%$. Oleh karena itu dana yang dicairkan $40 \%$ pertama menjadi modal apa yang perlu dibangun maka itu yang didahulukan untuk pelakanaan pembangunan desa.

Berdasarkan hasil penelitian disimpulkan bahwa mekanisme pengelolaan dana desa di Desa Melilian Kecamatan Gelumbang diawali dengan adanya pembentukan Tim Pelaksana Kegiatan (TPK) desa kemudian melakukan tahapan-tahapan yang harus diikuti sebelum melakukan pembangunan. Dalam melakukan perencanaan pemerintah Desa Melilian Kecamatan Gelumbang selalu melibatkan masyarakat untuk memberikan saran dan masukan untuk pembangunan desa.

\section{Perencanaan}

Dalam proses perencanaan pembangunan Desa Melilian Kecamatan Gelumbang sudah tertuang didalam Rencana Pembangunan Jangka Menengah Desa (RPJMDes). Rencana Kerja Pembangunan Desa (RPJMDes) akan menjadi petunjuk dalam pembangunan Desa Melilian Kecamatan Gelumbang dalam jangka waktu satu tahun berjalan. Berdasarkan dalam peraturan desa, Rencana Kerja Pembangunan Desa (RKPDes) akan menjadi dokumen yang utama dalam menyusun Anggaran Pendapatan Belanja Desa (APBDes).

Berdasarkan hasil penelitian dapat disimpulkan bahwa perencanaan pelaksanaan pembangunan Desa Melilian Kecamatan Gelumbang sudah melibatkan beberapa unsur yang terkait terutama dari kalangan masyarakat untuk melakukan musyawarah pra pembangunan agar sesuai dengan prioritas yang dibutuhkan masyarakat. Tujuan melakukan musyawarah yaitu agar pembangunan sesuai dengan apa yang telah disepakati bersama sehingga pembangunan dapat berjalan secara efektif dan efisien. Berikut adalah siklus dari musyawarah dalam perencanaan pembangunan yang dilakukan oleh pemerintah Desa Melilian Kecamatan Gelumbang.

Pertama dilakukan, Musyawarah Dusun (Musdus) karena musyawarah yang dilakukan di dusun dapat menentukan kebutuhan dari masyarakat masing-masing desa. Kemudian tahapan kedua dilakukan dengan mengadakan Musyawarah Desa (Musdes) di dalam musyawarah ini membahas dan mengumpulkan laporan dari masing-masing dusun mengenai arah pembangunan, kemudian pembahasan dilanjutkan dengan melihat kembali Rencana Pembangunan Jangka Menengah Desa (RPJMDes) untuk digunakan didalam penyusunan Rencana Kerja Pembangunan Desa (RKPDes). Sedangkan tahapan yang terakhir mengadakan Musyawarah Perencanaan Pembangunan Desa (Musrenbang), musyawarah ini merupakan forum tertingi yang dilakukan oleh pemerintah desa untuk membahas dan membuat keputusan rancanangan RKPDes.

\section{Pelaksanaan}

Berdasarkan Peraturan Menteri Keuangan Republik Indonesia Nomor 49 Tahun 2016 menjelaskan tentang tata cara pengalokasian, penyaluran, penggunaan, pemantauan dan evaluasi Dana Desa. Proses penyaluran dana desa diawali dengan pemindahan buku 
Rekening Kas Umum Negara (RKUN) kedalam Rekening Kas Umum Daerah (RKUD) kemudian selanjutnya melakukan pemindahan dari buku Rekening Kas Daerah (RKD) menjadi buku Rekening Kas Desa (RKD). Sedangkan pencairan dana desa di Desa Melilian Kecamatan Gelumbang dilakukan dengan dua (2) cara yaitu melalui transfer dan cash. Dalam melakukan pembelian bahan-bahan material untuk pembangunan pembayaran melalui ditransfer, kemudian dana cash hanya digunakan untuk upah tukang yang kita sediakan di bendahara desa.

Dari hasil penelitian dapat disimpulkan bahwa Desa Melilian Kecamatan Gelumbang Kabupaten Muara Enim melakukan seluruh penerimaan dan pengeluaran untuk pembangunan desa hanya menggunakan rekening kas desa. Selanjutnya pengambilan uang secara cash hanya dilakukan untuk beberapa keperluan seperti untuk ongkos tukang. Kemudian dengan adanya sistem pengelolaan keuangan desa secara terarah dapat terciptanya tatalaksana pemerintahan yang baik (Good Governance). Dengan adanya sitem pengelolaan keuangan yang baik tersebut akan lebih memungkinkan transparansi itu akan terjamin adanya.

\section{Penatausahaan}

Berdasarkan Peraturan Menteri Dalam Negeri Republik Indonesia (Permendagri) Pasal 35 menjelaskan bahwa Penatausahaan dilakukan oleh bendahara Desa. Dalam melakukan penatausahaan Bendahara desa berkewajiban melakukan pencatatan setiap penerimaan dan pengeluaran dana serta melakukan tutup buku pada setiap akhir bulan secara tertib dan disertai dengan bukti-bukti. Bendahara desa juga memiliki kewajiban mempertanggungjawabkan uang tersebut melalui laporan pertanggungjawaban. Laporan pertanggungjawaban tersebut akan disampaikan setiap bulannya kepada kepala desa dan paling lambat tanggal 10 bulan berikutnya.

Dari hasil penelitian dapat disimpulkan bahwa penatausahaan yang dilakukan oleh pemerintah Desa Melilian Kecamatan Gelumbang dilakukan secara bertahap dengan pengambilan dana secara merata untuk setiap pembangunan desa meliputi, pembangunan desa, pemberdayaan masyarakat, penyelenggaraan pemerintahan desa, dan pembinaan masyarakat desa. Pemerintah desa memiliki peran yang sangat penting dalam melakukan pencatatan baik itu penerimaan maupun pengeluaran dan juga melakukan penutupan buka pada setiap akhir bulannya, yang dibuat secara terperinci di dalam buku kas umum, buku bank, dan buku pemasukan. Dengan adanya pencatatan yang baik akan memudahkan pemerintah desa dalam melakukan pelaporan. Pencatatan juga di buat secara tertulis guna untuk menjadi cadangan jika ada masalah dalam proses komputer. Maka, untuk penatausahaan Dana Desa dilakukan dengan sistem keuangan desa yang saling terhubung dengan Rekening Kas Desa (RKD). Kemudian setiap pengambilan maupun pengeluran dan pemasukan dana baik itu dana yang sudah ditransfer atau penarikan secara tunai harus disertai dengan bukti sebagai Surat Pertanggungjawaban (SPJ).

\section{Pelaporan}

Berdasarkan Peraturan Menteri Dalam Negeri Republik Indonesia (Permendagri) Nomor 113 Tahun 2014 tentang pengelolaan keuangan desa. Kepala desa memiliki kewajiban untuk menyampaikan laporan realisasi pelaksanaan Anggaran Pendapatan dan Belanja Desa (APBDes) kepada Bupati /Walikota berupa laporan. Laporan semester pertama yang berupa laporan realisasi Anggaran Pendapatan dan Belanja Desa (APBDes) kemudian laporan realisasi pelaksanaan Anggaran Pendapatan dan Belanja Desa (APBDes) tersebut disampaikan paling lambat pada akhir bulan Juli tahun berjalan. Sedangkan laporan semester akhir tahun diisampaikan paling lambat pada akhir bulan Januari pada tahun berikutnya.

Berdasarkan hasil penelitian diketahui bahwa bentuk pelaporan yang dilakukan oleh pemerintah Desa Melilian Kecamatan Gelumbang dilakukan secara bertahap mulai 
E. ISSN : 2746-1629

dari sebelum pembangunan $0 \%$ sampai dengan hasil pembangunan $100 \%$. Kemudian dalam setiap pencairan Dana Desa pemerintah desa harus melampirkan buku laporan realisasi Dana Desa. Kemudian laporan realisasi Dana Desa juga dicantumkan didalam Anggaran Pendapatan Dan Belanja Desa (APBDes), untuk disampaikan kepada DPM melalui camat.

\section{Pertanggungjawaban}

Dalam penyelenggaraan pemerintahan terutama dalam pengelolaan Dana Desa tentu harus adanya pertanggungjawaban atas seluruh kegiatan yang telah dilaksanakan oleh pemerintah desa terutama pertanggungjawaban kepada pihak-pihak yang terkait. Pertanggungjawaban yang dilakukan oleh pemerintah desa yaitu harus membuat laporan tentang pengelolaan Dana Desa. Prinsip tatalaksana pemerintah yang baik (good governance) menjelaskan bahwa pertanggungjawaban tidak hanya disampaikan kepada satu pihak atau pihak pemerintah saja, akan tetapi harus disampaikan kepada seluruh masyarakat desa dengan harapan tidak ada terjadinya perselisihan antar pihak masyarakat dan pemerintah desa.

Berdasarkan hasil wawancara disimpulkan bahwa pertanggungjawaban yang dilakukan oleh pemerintah Desa Melilian Kecamatan Gelumbang terkait dengan pengelolaan Dana Desa yaitu pemerintah desa telah mempersiapkan dokumen-dokumen tentang rincian dan realisasi penggunaan maupun pengelolaan Dana Desa. Kemudian dokumendokumen tersebut disampaikan kepada pemerintah pihak-pihak yang terkait baik kepada pemerintah kecamatan maupun pemerintah kabupaten/kota. Pertanggungjawaban juga harus disampaikan kepada masyarakat secara jujur, jelas, dan adil seperti adanya papan informasi maupun baliho tentang penyelenggaraan pembangunan desa untuk mencegah terjadinya kecurigaan dan perselisihan didalam masyarakat dan pemerintah desa. Maka dapat disimpulkan bahwa mekanisme pengelolaan Dana Desa yang dilakukan oleh pemerintah Desa Melilian Kecamatan Gelumbang sudah terapkan dengan baik sesuai dengan Peraturan Perundang- undangan maupun ketentuan-ketentuan yang belaku. Kemudian proses pengelolaan Dana Desa pemerintah Desa Melilian Kecamatan Gelumbang juga sudah melibatkan masyarakat yang dimulai dari tahapan prencanaan, pelaksanaan, penatausahaan, pelaporan sampai dengan tahapan pertanggungjawaban.

\section{Transparansi Pengelolaan Dana Desa di Desa Melilian Kecamatan Gelumbang Kabupaten Muara Enim.}

\section{Adanya Ketersediaan Aksesibilitas} Dokumen

Indikator yang pertama yaitu dapat diukur dengan adanya ketersediaan aksesibilitas dokumen untuk meghindari terjadinya kecurangan dan penyalahgunaan dalam proses pengelolaan Dana Desa. Ketersediaan aksesibilitas dokumen diharapkan juga dapat memudahkan masyarakat desa untuk mengakses informasi tentang penyelenggaraan kegiatan pembangunan desa yang dilakukan oleh pemerintah desa. Dari hasil penelitian diketahui bahwa pemerintah desa selalu menyediakan dokumen dalam bentuk buku yaitu buku tentang realisasi anggaran yang tertuang didalam APBDes setiap tahunnya, dan buku tersebut sudah dituangkan ke dalam baliho untuk di pasang di desa supaya masyarakat mengetahui kemana anggaran itu dihabiskan.

2. Adanya Kejelasan dan Kemudahan Akses Informasi

Indikator yang kedua dapat diukur dengan adanya kejelasan dan kelengkapan informasi yang disediakan oleh pemerintah desa menjadi hal yang sangat penting untuk diketahui oleh masyarakat. Kemudian pemerintah desa harus dapat memberikan informasi yang jelas mengenai proses pelaksanaan pengelolan Dana Desa dengan cara melakukan pengawasan terhadap pelaksanaan pembangunan desa. Dari hasil penelitian diketahui bahwa warga selalu mendapat informasi dari Kepala Desa tentang kapan, dimana dan pembangunan apa yang akan dilakukan, terkadang masyarakat dan perangkat desa ikut serta dalam pembangunan sampai selesai. Setelah pembangunan selesai, di dalam rapat hasil pembangunan diumumkan oleh perangkat desa termasuk tentang anggarannya. 


\section{Adanya Keterbukaan Proses}

Indikator ketiga dapat diukur berdasarkan Undang-undang Nomor 14 Tahun 2008 pasal 7 ayat 2 tentang keterbukaan informasi menyatakan bahwa badan publik termasuk pemerintah desa berkewajiban menyediakan informasi publik yang akurat, benar, dan tidak menyesatkan. Seluruh masyarakat desa mempunyai hak untuk mengetahui proses pengelolaan Dana Desa secara menyeluruh. Dari hasil penelitian diketahui bahwa perangkat Desa telah menyediakan informasi tentang pembangunan desa dengan baik, baik itu melalui baliho maupun papan informasi. Informasi tersebut sudah disertai dengan total anggaran.

4. Adanya Kerangka Regulasi Yang Menjamin

Indikator yang keempat dapat diukur dengan adanya kerangka regulasi yang menjamin transparansi, pengelolaan Dana Desa pada dasarnya sudah diatur dalam Peraturan Pemerintah Nomor 60 Tahun 2014. Kemudian selain regulasi dan pertanggungjawaban pemerintah desa juga harus membuat laporan rincian anggaran beserta dokumen pendukung dalam setiap kegiatan proses pembangunan yang dilaksanakan dengan disertai dokumen. Dari hasil penelitian diketahui bahwa sudah memiliki kerangka yang jelas dan sudah transparansi dalam pengelolaan. Hal ini terlihat dari masyarakat diikutsertakan dalam kegiatan musyawarah pembangunan desa dari perencanaan hingga ke serah terima pembangunan.

Berdasarkan beberapa indikator diatas dapat disimpulkan bahwa pemerintah Desa Melilian Kecamatan Gelumbang sudah menerapakan keempat indikator transparansi tersebut serta melakukan tranparansi dengan melibatkan sejumlah masyarakat yang dimulai dari proses perencanaan pembangunan sampai dengan penerimaan dan penyerahan hasil pembangunan. Pemerintah desa melakukan transparansi dengan melakukan musyawarah bersama masyarakat dan tokoh-tokoh yang lain untuk membahas pembangunan apa yang akan dilaksanakan dengan anggaran yang telah dicairkan oleh pemerintah baik itu dana yang bersumber dari APBN maupun APBDes. Akan tetapi dalam musyawarah maupun pengawasan tersebut hanya diwakilkan oleh ketua seksi saja seperti, ibu PKK, ketua Linmas, ketua Karang Taruna, ketua Ibu pengajian, ketua pemuda, ketua ibu kader. Kemudian perwakilan tersebut yang menyampaikan keluh kesah atau aspirasi dari masyarakat yang berada dibawah pimpinannya. Kemudian pemerintah desa memberikan informasi mengenai pembangunan tersebut melalui papan informasi maupun baliho dengan jujur dan benar sesuai dengan kenyataan.

Dari beberapa pemaparan diatas dapat disimpulkan bahwa berdasarkan Undangundang Nomor 14 Tahun 2008 Tentang Keterbukaan Informasi Publik, Desa Melilian Kecamatan Gelumbang sudah menerapkan prinsip transparansi walaupun belum berjalan $100 \%$ namun, transparansi sudah dilakukan $75 \%$ dengan mengikutsertakan masyarakat dalam kegiatan musyawarah mulai dari perencanaan pembangunan desa sampai dengan serah terima hasil pembangunan masyarakat juga diikut sertakan.

Usaha pemerintah Desa Melilian Kecamatan Gelumbang dalam memberikan informasi secara jelas kepada masyarakat desa tentang penyelenggaraan pemerintahan baik itu informasi mengenai perencanaan sampai dengan hasil kegiatan yang telah dilakukan masih dilakukan secara manual. Penyampaian informasi kepada masyarakat dilakukan dengan adanya papan informasi dan baliho yang memberikan penjelasan secara terperinci agar masyarakat mudah memahaminya. Namun, pada masa modern ini Desa Melilian Kecamatan Gelumbang belum menggunkan teknologi seperti, belum tersediannya website yang dapat memberikan informasi secara menyeluruh kepada masyarakat yang berada diluar Desa Melilian Kecamatan Gelumbang serta masyarakat yang ingin mengakses informasi tentang pengelolaan dan kegiatankegiatan yang dilaksanakan oleh Desa Melilian Kecamatan Gelumbang. 
E. ISSN : 2746-1629

\section{E. PENUTUP}

\section{Kesimpulan}

1. Mekanisme pengelolaan Dana Desa di Desa Melilian Kecamatan Gelumbang Kabupaten Muara Enim sudah dilakukan berdasarkan Undang-undang Nomor 113 Tahun 2014. Hal ini terlihat baik pada tahap perencanaan, pelaksanaan, penatausahaan, pelaporan maupun pertanggungjawaban.

2. Dalam proses pengelolaan Dana Desa pemerintah juga sudah melibatkan masyarakat Desa.

3. Desa Melilian Kecamatan Gelumbang sudah transparan. Kemudian dalam pengelolaan keuangan Dana Desa sudah sesuai dengan perundang-undangan yang dilakukan dengan transparansi.

\section{DAFTAR PUSTAKA}

Amin Rahmanurrasjid, skripsi. "Akuntabilitas Dan Transparansi Dalam Pertanggungjawaban Pemerintah Daerah Untuk Mewujudkan Pemerintahan Yang Baik Di Daerah". Semarang: 2008. (Diakses pada tanggal 10 Oktober 2019 pukul 13:41).

Arista Widiyanti skripsi : “Akuntabilitas Dan Transparansi Pengelolaan Alokasi Dana Desa (Studi Pada Desa Sumberejo Dan Desa Kandung Di Kecamatan Winogan Kabupaten Pasuruan)". Fakultas Ekonomi Universitas Islam Negeri (UIN) Maulana Malik Ibrahim Malang. 2017.

Dwi Ristya Anggraini. 2013. Transparansi, Partisipasi, dan Akuntabilitas Pengelolaan Anggaran Dana BOS Dalam Program RKAS di SDN Pacarkeling VIII. Surabaya., Vol 1, No 2, Agustus. ISSN : 2303-34IX (Diakses pada tanggal 9 Oktober 2019 pukul 15:30).
I Wayan Irvan M, skripsi : "Penerapan Transparansi Pengelolaan Anggaran Pendapatan dan Belanja Desa, Studi Kasus Desa Sidoharjo Kecamatan Way Panji Kabupaten Lampung Selatan”. Fakultas Ilmu Sosial dan Ilmu Politik Uiversitas Lampung. 2017

Lalolo Krina. L. 2003, Indikator \& Alat Ukur Prinsip Akuntabilitas, Transparansi \& Partisipasi, Sekretariat Good Public Governance Badan Perencanaan Pembangunan Nasional. LAN dan BPKP.2003, Pedoman Penyusunan Pelaporan Akuntabilitas Kinerja Instansi Pemerintah. Jakarta:LAN RI.

Lutfiyah dan Fitrah M. 2017, Metodelogi Penelitian, Penelitian Kualitatif, Tindakan Kelas \& Studi Kasus. Jawa Barat : Cv Jejak.

Miftahuddin, skripsi: "Akuntabilitas Dan Transparansi Pemerintah Desa Terhadap Pengelolaan Dana Desa". Fakultas Ekonomi Universitas Islam Indonesia, Yogyakarta 2018.

Moore Barrington. 2008, Instrumen Penilaian Mandiri Dalam Pelayanan Publik Di Provinsi Daerah Istimewa Jogjakarta, Magister Administrasi Publik Universitas Gadjah Mada ; Centre for Policy Studies, Partnership for Governance Reform.

Peraturan lengkap desa. Undang-Undang Rebublik Indonesia Nomor. 6 Tahun 2014. Jakarta. Sinar Grafika

Republik Indonesia, Undang-Undang RI Nomor 60 Tahun 2014 Sebagaimana Telah Diubah Dengan PP No 22 Tahun 2015 Dan PP No 8 Tahun 2016 Tentang Dana Desa Yang Besumber Dari Anggaran Pendapatan Dan Belanja Negara. 2014 : Jakarta. 
Undang-Undang Republik Indonesia Nomor 6 Tahun 2014 Tentang Desa

Undang-undang Republik Indonesia Nomor 113 Tahun 2014 Tentang Pengelolaan Keuangan Desa

Undang-undang Nomor 14 Tahun 2008 Tentang Keterbukaan Informasi Publik

Rochmansja Heru dan Soleh C, 2015. Pengelolaan Keuangan Desa. Bandung: Fokusmedia.

Sugiyono. 2011. Metode Penelitian Kuantitatif, Kualitatif Dan $R \& D$. Bandung : PT Alfabet. 
P. ISSN: 2540-816X

Volume 3 Nomor 2 Edisi Maret 2021

E. ISSN : 2746-1629 